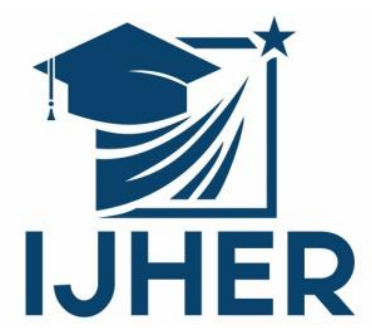

International Journal of Humanities and Educational Research

Volume 2, Issue 2, June 2020, p.45-56

İstanbul / Türkiye

\title{
SEMANTIC AND STRUCTURAL PERSPECTIVES OF MORPHOLOGICAL REDUCTION AND INCREASE
}

http://dx.doi.org/10.47832/2757-5403.2-2.3

\author{
Khalid Ahmed Hassan AHMED1
}

ISSN: 2757-5403

Article Information

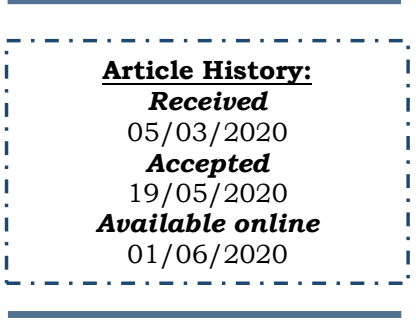

This article has been scanned by iThenticat No plagiarism detected

Copyright $($ C) Published by Rimak Journal, www.rimakjournal.com

Rimar Academy, Fatih, Istanbul, 34093 Turkey All rights reserved

\begin{abstract}
This study aims at exploring some morphological processes by which linguistic items can be reduced or increased in order to respond to some semantic and structural functions. This phenomenon is plausible in almost all human languages such as English and Arabic. Reduction and increase of morphological items serve variety of functions that range from structural precision to syntactic and semantic functions. This study is important as it attempts to present comparative and contrastive perspectives of English and Arabic instances of morphological reduction or increase. Some morphological aspects of both English and Arabic will be tackled. In addition to the analysis of the English morphological processes some verses of the Holly Qur'an will be taken as data for analysis. Moreover, some samples of other languages will be outlined to confirm the presence of this phenomenon in other human languages. To process this study a historical qualitative approach will be followed through an intensive survey and review of some related studies and samples of morphological reduction and increase. The study will include the objectives of the study, its methodology, results, summary and recommendations for further studies.
\end{abstract}

Keywords: Semantic Perspectives, Syntactic Perspective, Morphological Reduction, Morphological Increase, Harmony, Precision, Pidgins, Creoles, Language Varieties, Number, Gender, Case.

${ }^{1}$ Dr. khalidsoon@hotmail.com

\section{IJHER}

International Journal of Humanities and Educational Research

Volume 2, Issue 2, June 2020, p.45-56 


\section{Introduction:}

Language as a central human entity is generally identified as a system of systems. In other words the systems of a language or its layers are integrated and they influence each others. According to Leech (1985: 176) "Linguists, of whatever theoretical persuasions, have always regarded the complexity of language to be such that it is necessary to set up more than one level of analysis.", and how these levels are interrelated. The highest layer in the language is its semantics because the other layers or systems in the language run after composing a unit of meaning. The other systems of the language can be observed in this hierarchy of language in a descending manner the structural components of a language make its syntax, then its processes of words formation in terms of morphology, and its sound system as morphology. In this present study we are mainly interested in the semantic and structural consequences of the morphological processes, namely those of reduction and increase, in the overall structure of human languages. Human languages morphological processes of reduction and increase have great influences on the general semantic and structural components of nearly all languages. The components of meaning and structure are directly affected by these morphological processes. They may either be reduced or expanded by these morphological processes of reduction and increase. Each language has its own morphological processes although some similarities and differences can be established among languages if they are studied comparatively. In this present study special concern will be directed to the morphological processes of number, gender and case because we believe that they are mainly affected by these morphological processes.

According to Wardhaugh (2006: 69) in his discussion of pidgins and creoles maintains that the source language such as Arabic or English may be very rich in its morphological processes that affect number, gender, case, tense, etc. these morphological processes may be reduced or replaced by other separate entities to express more or less the same semantic or structural concept. Then Wardhaugh (ibid) applies some kind of a comparative survey among Arabic, Chinese and English with regard to the richness of the morphological processes, and he mentions that number in Chinese is only stated whenever it is relevant. The same is also true when the other varieties of a language such as English are studied it is observable that reduction of the sophisticated morphological processes is a common feature. Hudson (1996) agrees with Wardhaugh (2006) in that the morphological reduction is the distinguishing feature that helps in the creation of pidgins and creoles. Hudson (ibid) states that some languages may either lose a morphological system of numbers which is commonly replaced with

\section{IJHER}

International Journal of Humanities and Educational Research

Volume 2, Issue 2, June 2020, p.45-56 
separate indicators of number to maintain that a certain number is either big or small instead of using inflectional or derivational affixes to indicate that as it can be observed in the standardized languages of the world such as English and Arabic. For Bynon (1979: 33) the English number system which is developed through the different historical eras used to have variety of inflectional elements in terms of number itself, gender or case. This inflectional system has come to be reduced to the extent that number is a two - dimensional system as singular or plural. Then Bynon (1979: 147) says that number as an inflectional process can be observed in the structural processes of nouns and verbs as in "the boy sings, the boys sing". That is to say number is a unit that can be detected on the surface order of the English syntax. This is also true about all the other types of the inflecting or agglutinating languages that use clearly identified inflectional morphemes to run such morphological processes either in number, gender or case. However, the isolating languages, such as Chinese may lack such features of inflection or derivation because the different syntactic or grammatical components may be represented by completely separate forms rather than just inflectional or derivational elements.

Within the theoretical framework and the related studies more information and ideas will be stated about the morphological processes and their overall influence on both language meaning or semantics and language structure or syntax.

\section{The Importance of the Study:}

This present study is extremely important as it focuses on the impact of morphological reduction and increase on both semantic and structural perspectives of languages, mainly English and Arabic.

The study is also important as it is a qualitative holistic approach that tackles both religious and pure linguistic survey to establish some understanding of the elements of reduction and increase and their influences on meaning and structure.

The Islamic religious value of this study helps in reflecting positive views about the scientific perspectives of Islam as an intermediate religion that addresses a lot of the humanity values in todays' world.

\section{Methodology:}

This study is qualitative in nature; and to that end some of the essential related verses a long with their interpretations will be analyzed and studied to confirm the hypotheses raised in this study. The areas that will be of importance in this discussion will be: instances of reduction and increase in the Holly Qur'an and their influences on the interpretation and understanding of some verses in the Holly Qur'an.

On the part of the verses that will be outlined in this study three domains will be the focal core of discussion as follows: first the

\section{IJHER}

International Journal of Humanities and Educational Research

Volume 2, Issue 2, June 2020, p.45-56 
semantic value of morphological reduction and increase. Second the harmony between the deleted elements and the added elements on one hand and the semantic and structural values of these morphological processes. And thirdly the echoic influences of some oddly added morphological elements. On the part of the pure linguistic morphological elements, these morphological processes of reduction and increase will be discussed to reflect their semantic and structural values in languages, mainly English and Arabic. Some other languages will also be discussed to emphasize the presence of these mentioned morphological processes.

Special consideration will be directed to the morphological processes that inflect number, gender and case because we believe that these morphological processes affect languages and make differences among them. That is to say languages will either be limited or extended due to the presence or absence of some of these morphological aspects. For instances number and gender in Arabic and English present important morphological processes that allow us easily to apply comparative or contrastive analyses. Number in Arabic is a three dimensional inflected system, i.e. singular, dual, and plural; while it is a bi - dimensional process in English, i.e. singular and plural; therefore, Arabic and English may either converge or diverge as a result of this morphological process. The same is also true about gender differences, i.e. Arabic syntactic and morphological processes are widely influenced by gender differences, while English processes are very limited in terms of gender inflectional and structural processes.

\section{Procedure:}

This present research paper seeks to establish comparative contrastive analyses between the religious Arabic morphological aspects in the Holly Qur'an and Arabic language and those morphological processes in English language and some other languages. At the beginning of the analysis some selected related verses in the Holly Qur'an will be discussed supported by the interpretations of two famous interpreters of the Holly Qur'an Ibn Kathier and Altabarie. These verses will cover three central domains: the semantic values of the morphological processes of reduction and increase, their structural influences, and phonological echoing of some inserted morphological items. Then the analysis will be directed to the pure linguistic aspects in Arabic, English and some other languages mainly with reference to the aspects of number, gender and case. The related studies and the literature reviewed in this study will be of prime importance to set up the discussion, findings, conclusions and recommendations for further future studies.

The theoretical framework and some related studies:

\section{IJHER}

International Journal of Humanities and Educational Research

Volume 2, Issue 2, June 2020, p.45-56 
The theoretical frame work of this study will be built on what has been mentioned in the introduction to this study mainly that concerns ideas about number gender and case. According to Lyons (1979: 239) languages within a given context are identified with some kind of 'concord or agreement' within their constructional units regarding number, gender, tense and case. This language context is the fundamental component on which reduction and insertion work. These morphological processes of reduction and insertion may decrease or increase this structural context. Then Lyons (ibid) went on mentioning some instances of agreement within the strings of the structural components where it is observable that the agreement within the parts regarding French is more than that of English because in French there is a structural agreement regarding gender which is very limited in English. This kind of comparison between French and English is also applicable between English and Arabic, as it has been mentioned before that Arabic inflectional and derivational components are greater than those found in English. Then Lyons (1979: 240) explains that in 'Italian, Spanish, German, Russian, Latin, and in many other languages' there should be agreement between the adjective and the noun in terms of number and gender. The same kind of relationship between the noun and the adjective could also be established between the verb and the subject or object or both subject and object. In English we find such agreements as: I go, you go, they go and he goes, where the addition of the ' $s$ ' indicates present simple singular forms. The forms of verb to have (have and has) and those of verb to be (am, is, was, are and were) are also instances of agreements between subject and verb as singular or plural markers, such as (he/she/ it + has/is or was and as plural forms with we/you/ they + are or were, etc.).

Another further important factor in our discussion is that of case by which a noun, a pronoun or an adjective could either be nominative, accusative or dative, etc. Case inflection may be somewhat limited in English, but it is more extended and complicated in other languages such as Latin or Turkish as can be seen in the tables below taken from Lyons (1979: 290 - 91).

Table 9. Three Latin Declensions (The lexeme PUELLA 'girl' is feminine, LUPUS 'wolf' is masculine, BELLUM 'war' is neuter.)

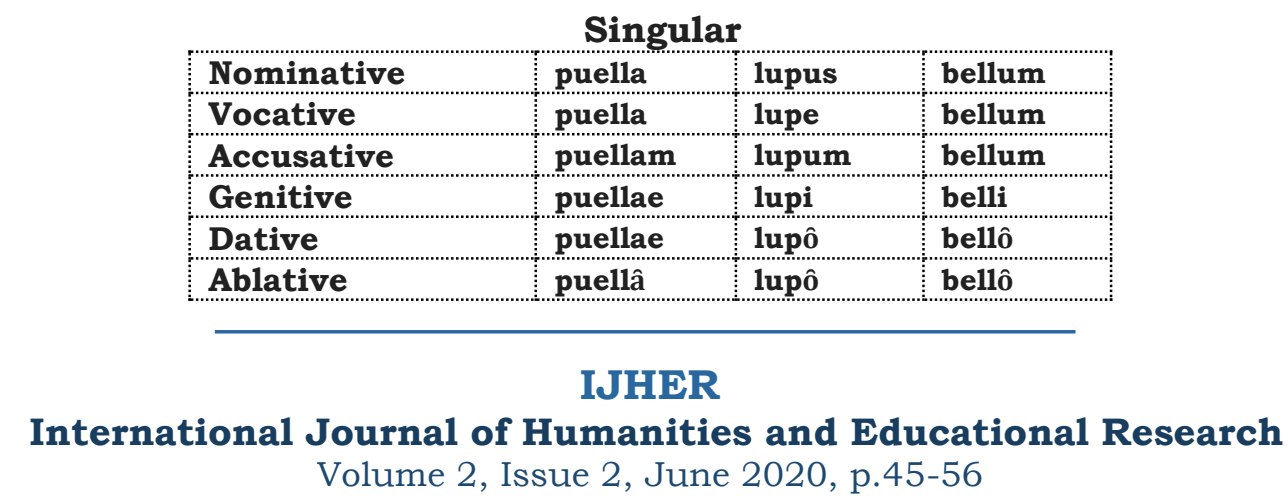




\begin{tabular}{|c|c|c|c|}
\hline \multicolumn{4}{|c|}{ Plural } \\
\hline Nominative & puellae & lupî & bella \\
\hline Vocative & puellae & lupî & bella \\
\hline Accusative & puellâs & lupôs & bella \\
\hline Genitive & puellârum & lupôrum & bellôrum \\
\hline Dative & puellîs & lupîs & bellîs \\
\hline Ablative & puellîs & lupîs & bellîs \\
\hline
\end{tabular}

Table 10. Case and Number in Turkish

\begin{tabular}{|l|l|l|}
\hline \multicolumn{1}{c}{ Singular } & Plural & \\
\hline Nominative & ev & evler \\
\hline Accusative & evi & evleri \\
\hline Genitive & evin & evlerin \\
\hdashline Dative & eve & evlere \\
\hline Locative & evde & evlerde \\
\hline Ablative & evden & evlerden \\
\hline
\end{tabular}

Nominative in the tables above denote the subject of a sentence, accusative for the object, vocative for address, genitive for possession, dative for indirect objects, ablative for different functions such as the tool by which something is done, and locative implies place. From the tables it is clear that in some cases the same form may be repeated; however, in the case of English language such an extended mode of case declensions may not be found as such mainly for nouns. Some instances of case inflection may be noticeable in pronouns such as: I, me, my and mine, he, him, his, she, her, hers, you, your, yours, they, them, their, theirs, we, us, our and ours, and it and its. The noun is never changeable for case as we say: "The girl will come, and 'I met the girl' although the noun 'girl' is in two different cases namely nominative and accusative. The apostrophe's' may be the only genitive case for English nouns. In Arabic the case is also marked by final declensions in terms of macrons that are put at the end of the noun 'fathah, dhamma, or kasra.

$$
\text { الفتحة، الضمة والكسرة: ضرب الولد الجرس، مررت بالولد. }
$$

For Denham and Lobeck (2010: 162) the inflectional morphemes have their grammatical aspects when added to roots or lexical items. The absence or reduction of inflectional forms may be the outcome of some phonological features as it has been stated by Delsing (2002: 937) when he says that "weakening of vowels in unstressed syllables causes severe reductions in the morphological system. ... All gender and case distinctions disappear among the weak nouns in the sg. ... .In the weak adjectival paradigm all case, number and gender distinctions are lost.". It seems the reduction initially is resulted by phonological processes, but it is later confirmed by the established morphological processes. According to Enger (2013: 7) sound or phonological reduction cannot

\section{IJHER}

\section{International Journal of Humanities and Educational Research}

Volume 2, Issue 2, June 2020, p.45-56 
be considered the prime source for cases or gender loses because at one hand there are instances of reductions that have nothing to do with the phonological processes such as the reduction of the genitive $-\mathrm{s}$ in most North Germanic languages as the loss of the final $-\mathrm{s}$ is not in essence phonological. Moreover, the reduction of the morphological markers, have also been proved to be a matter of sociolinguistic factors due to the contacts that the languages or their varieties may have with other higher social groups. Enger (2013: 21) concludes his observations about reduction in North Germanic languages by saying that: "The Scandinavian case and gender reduction cannot be attributed only to phonology, not even when supplemented by contact. Both have a role to play, but if we must choose one 'prime mover', morphology seems the best candidate, which fits the recent emphasis on autonomous morphology,".

The related studies will mainly tackle the morphological and phonological processes that affect the linguistic phenomena of reduction and increase. According to Babiker and Ahmed deletion in human languages is a common feature that runs after deleting the morphological components that can be derived from the attached context easily by the addressee. In Arabic this phenomenon grants a kind of precision to the Arabic expressions. As a starting point it is observable that a lot of verses in the Holly Qur'an present such phenomena clearly. Reduction and increase in the Holly Qur'an play a vital role in enriching its verses with more powerful elements of clarity, portrayal and harmony. That is to say any reduction or increase in the morphological aspects help interpreters grasping the imbedded meanings and attain language harmony and expressive precision. For example Al - Najar (2014) in his study entitled "Aspects of Phonological Implications in the Holly Qur'an" says that sentences of the Holly Qur'an acquire their harmonic beauty through a conjugation between the rhetoric expressive features and the phonological techniques of the Arabic language. Al-Najar (ibid) confirms his assumptions by discussing some verses in the Holly Qur'an that bear witness to the presence of reduced and added morphological processes. In a similar study by Salih and Babiker (2004) who studied the influence of the added letters on the morphological processes, and they summed up these letters in the term "Itumuneaha". These processes of addition to verbs and nouns have been supported by the discussion and analysis of some verses from the Holly Qur'an.

In another similar study $\mathrm{Abu}$ - Iesa stated that morphological reduction is a common phenomenon in all human languages. However, in Arabic language this phenomenon is a central one as it helps Arabic language to preserve language clarity and precision. Moreover, Arabs prefer to deal with lightly uttered expressions than those hard and heavy ones. Then he mentioned the necessities for morphological reductions such

\section{IJHER}

International Journal of Humanities and Educational Research

Volume 2, Issue 2, June 2020, p.45-56 
as: the intensity of language use, the wordy expressions, for poetical uses, for morphological, syntactic and phonological functions; and he mentioned examples for each case. Magoora (2016) has also studied the extension letters in the Holly Qur'an with reference to (Surat Al Sajdaa) he concluded this study by the main findings the most important of which, and which are directly related to this present study are: the extension letters are identified by their morphological and syntactic features, these letters are used either for more semantic values or for relating a structure with another structure or for emphasis, or they are used to add more semantic values to the structural content. All these results have been confirmed by the mentioning of verses from the Holly Qur'an.

The majority of the related studies exemplify the morphological processes of insertion and Reduction with reference either to some verses from the Holly Qur'an, or other similar linguistic texts, or syntactic, semantic and phonological processes because these processes are pure linguistic phenomena that are best explained through pure linguistic data. Some researchers have also considered these processes in a comparative contrastive manner such as Saab and Lipt'ak (2015) who studied Hungarian and Spanish languages mainly with reference to noun phrase ellipsis and the morphological, syntactic or semantic need for this reduction. They exemplify their study by instances from the two languages followed with their English equivalents. In another study on Japanese Menezes and Quirk (2008: 735) say that 'function words' have semantic values when added to a stem of a Japanese structure; they have case denotations. If they are inappropriately used in a sentence, these sentences may turn out to be unreadable.

\section{Discussion, Results, Conclusion and Recommendations:}

In this part of the study, we will start with some selected verses from the Holly Qur'an which will be discussed and followed with their English translation and the famous interpretations given to these verses, mainly as stated before by Ibn Kathier and Altabarie.

The first domain will be devoted to the semantic and structural values that will be taken from these verses.

First, it is well known in the Holly Qur'an that some "Sorahs" and verses start with some clipped letters as in the following verses:

بمم الله الرحمن الرحيم

1. . الم) "Al-Baqarah", “Al-Imran”, "Al-Ankabut”, "A1-Rum”, "Luqman”, "Al-Sajdah"

2. "الرص(الرئ "Al-A'raf"

3. (1)... الر "Yunus" "Hud" "Yusuf"

\section{IJHER}

International Journal of Humanities and Educational Research

Volume 2, Issue 2, June 2020, p.45-56 
4. (1)... المر "Al-Ra'd" "Ibrahim" "Al-Hijr"

5. (1)“" كهيعص "Maryam”

6. (1) " طه "Taa - Haa”

7. (1) طسم "Al-Shuara" "Al-Qasas

8. (1) طس "Al-Naml”

9. (1) "بaseen"

10. (1) .... "Sad"

11. (1) "Ghafir" "Fussilat" "A1-Shura" "Al-Zukhruf" "A1-Dukhan" "A1Jathiyah" "Al-Ahqaf"

12. (1) .... "Qaf"

13. (1) .... "Al-Qalam"

These clipped letters provide us with clear instances of reduction. Hence, interpreters, have different interpretations for these letters. However, the majority of them agreed that these clipped letters resemble Allah's greatest name. Others believe that, these letters are only titles for these "Surahs" and the perfect knowledge of these clipped letters is of a Devine source and we as human beings have no access to know their exact meanings. Still others believe that the letters present a summary of the content of the "Surahs". For us the most important thing is that these letters provide us with a clear example of reduction that includes syntactic and semantic implications that clearly address our present study and confirms its hypotheses.

In sorat Al - Kahf there are direct clear examples of insertion and reduction that address the hypotheses of this present study.

بسم الله الرحمن الرحيم

قال انك لن تسنطيع معي صبرا (67) He (Khidr) said: 'No doubt, you will not be able to have patience being in my company'.

"is used in its full morphological form تستطيع In this verse the word "be able“.

To imply semantically that the matter of following this good man and comprehending his deeds would be difficult for the Prophet "Moses" to comprehend and afford due to his lack of the Divine knowledge needed in this private condition. In other words the full use of the term implies a semantic harmony between the used word and its level of difficulty. In another verse the same word "تنستطيع" is reduced to be "نسطع" to present another example of the harmony between the morphological form and the semantic import that indicates the level of difficulty:

بسم الله الرحمن الرحيم

(82.... ذلك تأويل ما لم تسطع عليه صبرا (1)

\section{IJHER}

International Journal of Humanities and Educational Research

Volume 2, Issue 2, June 2020, p.45-56 
The meaning here is intended to indicate that the case is reflected and the knowledge is grasped; therefore' the comprehension can easily be dealt with, or the level of difficulty is reduced or vanished at all. Another evidence of the value of morphological insertion and reduction is also found in 'Sorat - Al - Kahf'.

$$
\text { بسم الله الرحمن الرحيم }
$$

فما اسطاعوا أن يظهروه و ما استطاعوا له نقبا (97)

In this verse the contrast between the two words "اسطاعوا - استطاعوا" or a complete word with its full morphological structure and the reduced one indicate also that the intended meaning is that of the levels of difficulty and easiness. That is to say it is somewhat easy to climb a hill or a mountain than to dig into it to make a hole or a passage to pass through.

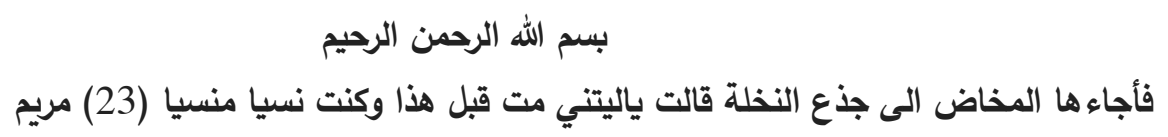

"Then the birth pangs drove her to the trunk of a palm - tree. She said (in anxiety): 'Would that I had died before this and had become totally forgotten!" Mary 23.

In the above verse of "Sorat Mariyam" the word فأجاءها is the intended word because it is a special insertion of a word to fit the situation. It is said that this verb is a three - dimensional verb to imply that birth pangs attack her suddenly due to the fact that she was not certain about it, and that the pangs made her move towards the date palm trunk. Therefore, the verb with this form suits the whole circumstances.

$$
\text { بسم الله الرحمن الرحيم }
$$

تلك اذا قسمة ضيزى (22) النجم

(If your concept is correct,) Then that Division is serious Injustice. (22) 'Alnajm'.

The word ضيزى "dheezah" is also an odd expression to imply at one hand a complete injustice division, and on the other its sound gives this impression of something that is unfavorable. This point confirms our assumption that sometimes the insertion of a morphological or phonological term may be used to give a harmony between the inserted word and the context at which it has been inserted.

In the overall language structure it is plausible that there is a harmony between the morphological insertions and deletions mainly in terms of number, gender and case; i.e. the languages that have a lot of

\section{IJHER}

International Journal of Humanities and Educational Research

Volume 2, Issue 2, June 2020, p.45-56 
inflectional or derivational processes for these linguistic classes are expected to have more elaboration or limitations in terms of their syntactic and semantic processes. For example number in English is a two dimensional process, i.e. singular and plural, while the number distinctions in Arabic are of three dimensions, i.e. singular, dual and plural the thing that makes it important in Arabic to have a more advanced system in Arabic while it is somewhat limited in English. Moreover, some languages may lack these number distinctions; instead they use somewhat a kind of interjections to express number distinctions the thing that makes such languages very limited in the area of number distinctions.

Gender and case are also elements of linguistic expansions of limitations. In Arabic for example these distinctions are very developed and sophisticated and all the word classes are affected by them the thing that may result in some cases to some kind of ambiguity in English for instance. For example words such as teacher, engineer, nurse, aunt, uncle, etc. may not be grasped in a given linguistic context while they are what some easy to distinguish in Arabic language due to the presence of gender, and case distinctions, inflections and derivations. Therefore, the availability of gender and case declinations will result in more syntactic and semantic sophistications and expansion.

\section{Results, Recommendations and Conclusion:}

From the reviewed selected verses from the Holly Qur'an, and the review of the related literature, and the discussion following results will bring the discussion to a logical end to indicate that morphological insertion and reduction have the following syntactic and semantic values:

1. Morphological reduction and insertion play important roles in semantic and structural clarity and precision.

2. There is some kind of harmony between the deleted and the inserted morphological elements and the obtained structural and semantic units.

3. The presence of certain morphological features in language may help in disambiguating some structures.

4. The lack of some morphological units reduces languages sophistication and structural and semantic clarity.

5. Some inserted morphological elements may help in providing phonological harmony to serve the context at which they are added.

In the light of these obtained results the following recommendations will bring the topic to further discussions and future studies:

1. Ambiguity and morphological insertion and deletion.

2. A comparative study between agglutinating and inflecting languages in the light of the morphological insertion and reduction.

3. Morphological insertion and reduction in the Holly Qur'an.

\section{IJHER}

International Journal of Humanities and Educational Research

Volume 2, Issue 2, June 2020, p.45-56 


\section{Sources:}

- The Holly Qur'an.

- The Glorious Qur'an.

- Altabarie Interpretation of the Holly Qur'an.

- Ibin Kathier Interpretation of the Holly Qur'an..

\section{References:}

- Al - Najar (2014) Aspects of Phonological Implications in the Holly Qur'an.

- Babiker, Ahlam Ali and Ahmed, Aboud Mohammed (2017) Deletion in Arabic among Scholars of Syntax, Rhetoric and Linguistics. SUST Journal of Humanities. Vol. 18. No3 September (2017).

- Bynon, Theodora (1979) Historical Linguistics. Cambridge Textbooks in Linguistics.

- Delsing, Lars-Olof. (2002.) "The Morphology of Old Nordic II: Old Swedish and Old Danish".

- Denham, Kristin and Lobeck, Anne (2010) Linguistics for Everyone An Introduction. Wadsworth, Cengage Learning.

- Enger, Hans - Olav (2013) Inflectional change, 'sound laws' and the autonomy of morphology: The case of Scandinavian case and gender reduction. John Benjamins Publishing Company.

- Hudson, R. A. Sociolinguistics, second edition; copyright ( 1996 by Cambridge University,

- Leech, Geoffrey (1985) Semantics - The Study of Meaning Second Edition. Penguin Books.

- Lyons, John (1979) Introduction to Theoretical Linguistics. Cambridge University Press.

- Magoora, Nasr Al - Deen. (2016) “The Additional Letters of the Holly Qur'an. Mohammed Bu Dhiyaf University Algeria - unpublished M. A. Thesis.

- Menezes, Arul and Quirk, Chris (2008) Syntactic Models for Structural Word Insertion and Deletion. Association for Computational Linguistics.

- Saab, Andres \& Liptâk, Anikô (2015) Movement and Deletion after Syntax: Licensing by Inflection Reconsidered* A Journal of Central Linguistics.

- Salih, Insaf Abdallah Mohammed and Babiker, Othman Alfakie (2004) The Morphological Implications of the Added Letters. University of Khartoum. Post Graduate College

- Wardhaugh, Ronald (2006) An Introduction to Sociolinguistics. Black Well Publishing.

\section{IJHER}

